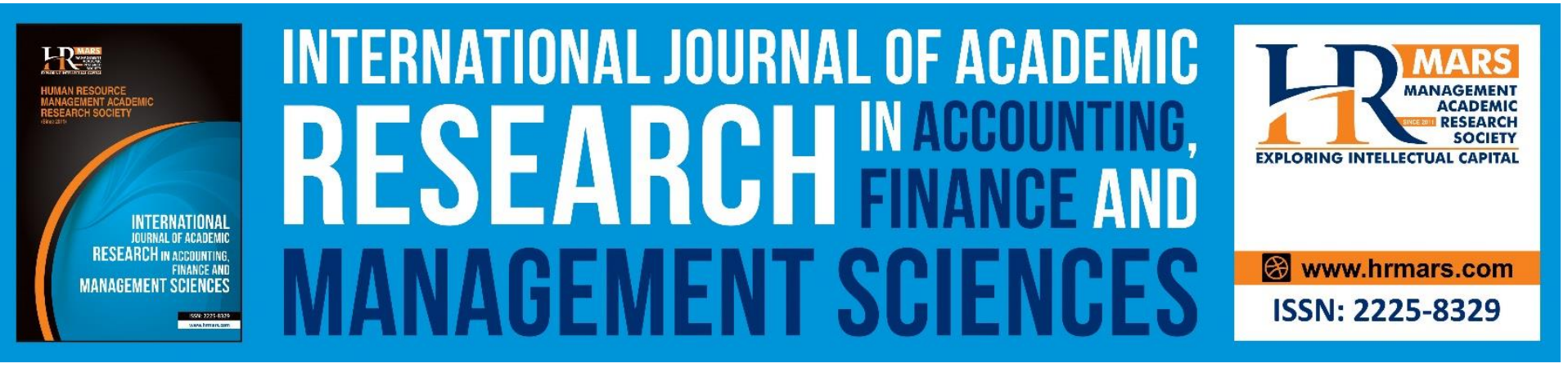

\title{
International Financial Flows its Effects on Economic Growth in Jordan
}

Amjad S. Qwader

To Link this Article: http://dx.doi.org/10.6007/IJARAFMS/v11-i1/8861

DOI:10.6007/IJARAFMS /v11-i1/8861

Received: 20 December 2020, Revised: 16 January 2021, Accepted: 25 January 2021

Published Online: 18 February 2021

In-Text Citation: (Qwader, 2021)

To Cite this Article: Qwader, A. S. (2021). International Financial Flows its Effects on Economic Growth in Jordan. International Journal of Academic Research in Accounting Finance and Management Sciences, 11(1), 37-56.

Copyright: (C) 2021 The Author(s)

Published by Human Resource Management Academic Research Society (www.hrmars.com)

This article is published under the Creative Commons Attribution (CC BY 4.0) license. Anyone may reproduce, distribute, translate and create derivative works of this article (for both commercial and non-commercial purposes), subject to full attribution to the original publication and authors. The full terms of this license may be seen

at: http://creativecommons.org/licences/by/4.0/legalcode

Vol. 11, No. 1, 2021, Pg. 37 - 56

http://hrmars.com/index.php/pages/detail/IJARAFMS

JOURNAL HOMEPAGE

Full Terms \& Conditions of access and use can be found at http://hrmars.com/index.php/pages/detail/publication-ethics 


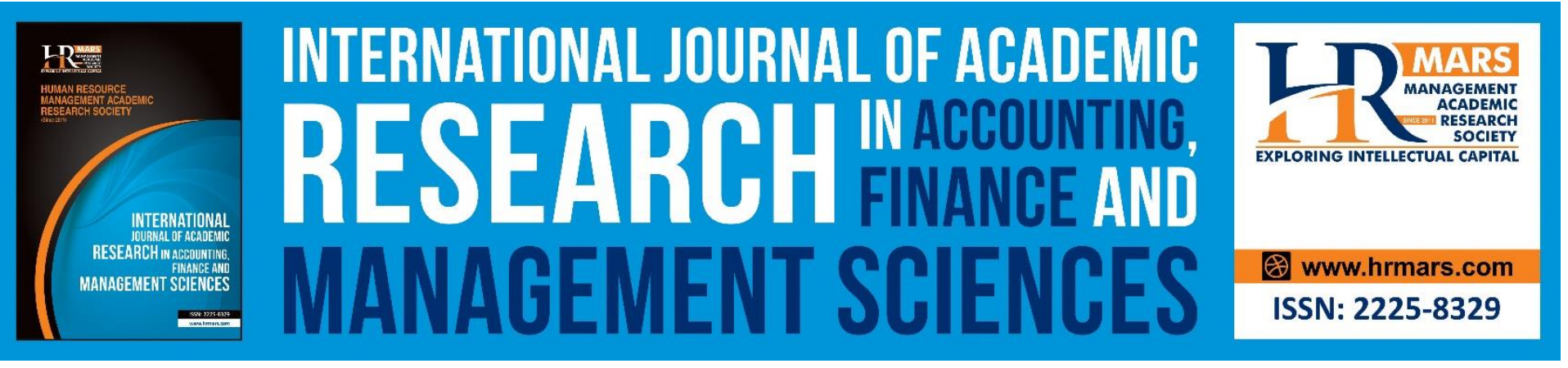

\title{
International Financial Flows its Effects on Economic Growth in Jordan
}

\author{
Amjad S. Qwader \\ College of Business, Tafila Technical University, AT-Tafila, P.O. Box 179, Tafila, 66110, Jordan \\ Email: amjad.qwader73@gmail.com
}

\begin{abstract}
This study aims to measure the effects of international financial flows represented in exports, remittances of overseas workers, foreign direct investment, and external grants on the economic growth in Jordan during the periodfrom 1990 to 2018. The study used self-regression for the distributed slowdown periods. The study obtained several important results. First, the study found the presence of a significant and positive effect of foreign exports and grants on economic growth in the long and short term. The study also concluded the existence of the significant and negative effect of workers'remittances on economic growth in the long term, and the insignificance of the effect in the short term. The results indicate that the effects of foreign direct investment on economic growth in the long and short term areinsignificant. The study offers aset of recommendations, including the adoption of the Jordanian government ofa policy that encourages exportsbased on the introduction of national exportable products and the improvement of the quality of Jordanian products. Jordanian workers should be facilitated to work in the foreign markets and their remittances should be utilized for investment purposes instead of spending them for consumer purposes.Periodic reviews of the institutional and legal frameworks pertaining to encouraging investment in Jordan should be conducted and external grants should be directed towards priority projects for the Jordanian economy.
\end{abstract}

Keywords: International Financial Flows, Economic Growth, Exports, Workers' remittances, External Grants, Foreign Direct Investment.

\section{Introduction}

Economic growth is one of the most important economic goals of governments in developed and developingcountries of the world. Achieving this goal requires large amounts of capital that exceed the available domestic financial resources of any country, and thus, the deficiency must be financed through the flow of international capital into the interior during the same period to bridge the gap in the local financial resources prepared for economic growth in this area. The movement of international financial flows between countries of the world is an important source of international financing. 
INTERNATIONAL JOURNAL OF ACADEMIC RESEARCH IN ACCOUNTING, FINANCE AND

MANAGEMENT SCIENCES

Vol. 11, No. 1, 2021, E-ISSN: 2225-8329 @ 2021 HRMARS

The importance of these flows has increased over the past few years and they have been a source of concern for many countries, especially developing countries. The governments of these countries have striven to attract international financial flows of all kinds and have tended to restructure their economies and adopt plans and programs to achieve reform and economic stability. It has also adopted policies that would address the public budget deficit and balance of payments, all to improve the local investment environment, integrate into the global economy, and keep pace with globalization to enable these governments to interact positively with renewed international developments in the field of foreign trade and the flows of funds across borders.

Despite the variations in the size of financial flows and the geographical distribution between countries and regions around the world, however, since the 1970s, financial development and liberalization began, especially in the international financial markets, which led the increase in privatizations and economic openness and the emergence of many economic blocs. Financial flows have a clear effect on most developing economies and many economists believe the progress and growth of any economy are relatedclosely to the extent of those financial flows being able to reach it.

Accordingly, if the international financial flows are obtained and exploited better, it can have an effective influence on the economic activitiesof the country receiving it. Thus, the problem of the study crystallizes around the following question: "To what extent do international financial flows contribute indriving economic growth in Jordan?"

This research question is divided into several sub-questions, as follows:

What are the effects of exports on economic growth in Jordan?

What are the effects of workers' remittances on the economic growth in Jordan?

What are the effects of foreign direct investment on economic growth in Jordan?

What is the effect of external grants on economic growth in Jordan?

\section{Importance of the Study and its Objectives}

The issue of international financial flows is of great importance in the economies of many developing and developed countries because of the positive role that it can play in terms of economic growth and the consequent opening of investment horizons, and contribute to solving the problem of unemployment and raising their level of income, thereby raising the standard of living for the community. Therefore, the importance of this study lies in identifying the most important forms of international financial flows to Jordan and tracking their development, determining their effects on economic growth, verifying the feasibility of economic policies adopted toattract financial flows and international financial flows, and formulating several recommendations that would affect the structure of these flows, thereby improving macroeconomic variables, chief among them is economic growth.

\section{Accordingly, the Objectives of the Study can be Defined as Follows}

- To recognize the importance of international financial flows in economic thought and itsrole in achieving economic growth.

- To study the performance of international financial flows and their development in Jordan during the study period.

- To identify the relationship between international financial flows and economic growth in Jordan. 
INTERNATIONAL JOURNAL OF ACADEMIC RESEARCH IN ACCOUNTING, FINANCE AND

MANAGEMENT SCIENCES

Vol. 11, No. 1, 2021, E-ISSN: $2225-8329$ @ 2021 HRMARS

- To present the appropriate proposals and recommendations that would raise the performance and role of international financial flows in the positive and effective effectson the economic growth of the Jordanian state.

\section{Study Hypotheses}

This study relies on a set of assumptions that aim to answer the problem of the study. These assumptions fall are related to the determination of the effects of international financial flows on economic growth, which has been formulated in the following form:

- No positive statistically significant effect can be observed between exports and economic growth in Jordan.

- No statistically significant positive effect can be observed between the remittances of overseas workers and economic growth in Jordan.

- A positive, statistically significant effect exists between foreign direct investment and economic growth in Jordan.

- No statistically significant positive effect can be observed between external grants and economic growth in Jordan.

\section{Theoretical Framework and Previous Studies}

Countries pursuit of international financial flows is due to the active role that these flows can play in the economic activity of the countries that receive them. The economic and financial literature is rich in studies on the relationship that links international financial flows to economic activity and its various indicators, especially economic growth. In this regard, the relationship that links the different forms of international financial flows with economic growth can be addressed as follows:

First: The relationship between exports and economic growth

Economic thinkers have highlighted theimportance ofexport activitiesand its relationship to economic growth. According to the classical economic thinkers, the establishment of international trade based on the differences in relative expenditures would reinforce the principle of specialization in the production of export commodities, thereby improving and raising the level of productivity in the export sector. As for the Keynesian thought, exports are one of the most important components of national income because they contribute to an increase in income greater than their direct value through the action of the multiplier. Several economists have posited a different view on the role of exports in the economic development process, including Marx, who pointed out the impossibility of foreign trade playing an active role in the economic development of developing countries because of the considerable control that capitalist countries exert over international economic relations and their exploitation, that is, plundering the wealth of poor and weak countries. For Myrdal, he believes that "the large markets created by foreign trade work in the first place to enhance the status of developed countries that already have a strong industry, unlike developing countries that have weak industry (Al Sawai, 2005).

The results of studies on the relationship of exports and their effects on economic growth indicated differenced, wherein some studies have confirmed the existence of a positive effect of exports on economic growth, while others confirm the existence of a negative effect of exports on economic growth, For example,Behnam (2019) confirmed that exports have a positive effect on economic growth and that they play the role of the engine for economic growth in Malaysia. The same view is confirmed by Bourahla \& Boutouba (2013) who focused on the Algerian economy. Alraimony (2011) 
INTERNATIONAL JOURNAL OF ACADEMIC RESEARCH IN ACCOUNTING, FINANCE AND MANAGEMENT SCIENCES

Vol. 11, No. 1, 2021, E-ISSN: 2225-8329 @ 2021 HRMARS

highlighted the important positive effect of export growth on the real output in Jordan, and Mendoza (2017) showed the positive and weak effect of export growth on the Mexican economic growth. Meanwhile, Bakari (2017) found a negative effect of exports on economic growth in Gabon. Badreldin (2018) also showed the negative effect of exports on the Sudanese GDP, which is due to the lack of a clear economic policy regarding Sudanese exports.

\section{Second: The Relationship of Workers'remittances from Abroad with Economic Growth}

The issue of workers'remittances from abroad has always attracted the attention of researchers, think tanks, decision-makers, and international financial organizations because they represent one of the most important sources of external financial flows. Remittance flows of workers around the world increased from $\$ 9.1$ billion in 1970 to more than $\$ 706$ billion in 2017 according to World Bank estimates. In this regard, the report of the United Nations Conference on Trade and Development (UNCTAD, 2012) indicated that a large number of studies have highlighted the positive effects of financial transfers for workers abroad in terms of reducing poverty and diversifying sources of income. The report showedthat the evidence on the relationship of remittances to economic growth indicates that it is a multi-faceted one. On the negative side, remittances may limit economic growth, especially if the culture of reliance on external remittances has been established. On the positive side, remittances would support economic growth and the development of the economy's production capacity in general. The two channels are investment and deepening the financial market by enhancing the accumulation of physical and human capital.Among the previous studies that examined the relationship of remittances of overseas workers to economic growth, Athamneh\& AlZu'bi (2008) concluded that remittances of Jordanian workers abroad had a positive effect on economic growth and that these remittances were directed mainly towards spending. Private consumption higher than the trend of spending on investment, and thus, its effects on the economic growth was modest. Adusah (2016)confirmed the existence of a positive and significant effect ofworkers'remittances on economic growth in the long and short term, concerning the South African economy. Jawaid \& Raza (2012) concluded the existence of a positive relationship between remittances of overseas workers and economic growth in Korea, but a large negative relationship between remittances of workers and economic growth in China. Karagoz (2009) also indicated that the influx of workers'remittances negatively affectedeconomic growth in Turkey.

\section{Third: The Relationship of Foreign Investment with Economic Growth}

Foreign direct investment plays an important role in achieving economic growth in the recipient countries by coupling foreign direct investment with many positive aspects that can affect economic growth, including improving the local business environment, obtaining modern technological capabilities and tools, developing administrative and organizational knowledge skills, providing more job opportunities, raising the level of productivity, and stimulating and integrating it with local investments, therebyadvancing economic growth (Wahid, 2019). The flows resulting from this activity may also have negative effects on the economic performance of the host countries because these flows may be an alternative to domestic savings, which has the effect of crowding out local investments and transferring traditional and old technology. Technology can be used to replace work, which reduces employment opportunities and reverses the flow of profit remittances if the transfer pricing practices and large concessions granted by host countries to attract these investments are considered (Chowdhury \& Mavrotas, 2003). 
INTERNATIONAL JOURNAL OF ACADEMIC RESEARCH IN ACCOUNTING, FINANCE AND MANAGEMENT SCIENCES

Vol. 11, No. 1, 2021, E-ISSN: 2225-8329 @ 2021 HRMARS

The results of previous applied studies have shown inconsistencies on the effects of foreign investment on economic growth. Among these studies,Insah (2013)found the positive and statistically significant effects of foreign direct investment on economic growth in Ghana. Onu (2012) also confirmed that foreign direct investment has the potential to positively affect Nigeria's economic growth despite its insignificant contribution to the GDP during the study period. Hussein (2009) identified a weak positive relationship between foreign direct investment and economic growth in the Gulf Cooperation Council countries. Rahman (2015)used statistical analysis and found a slight positive effect between foreign direct investment and economic growth in Bangladesh. Several factors were identified to be the most important, includingthe unskilled workforce, inadequate infrastructure, slow privatization process, bureaucracy, political instability, and the recurrence of natural disasters.

\section{Fourth: The Relationship of External Grants to Economic Growth}

The effect of external grants on economic growth depends on the economic policies of the recipient countries. These countries must ensure that these funds are used in productive projects that yield a reasonable rate of return and take care to mobilize their domestic financial resources to the maximum extent possible (UNCTAD, 2008). In this regard, Alkousini\&Shawaqfeh(2020)believedthat the effects of grants on economic development and growth may be limited and short-term if they are spent on areas of government administration. Meanwhile, the effects may be strong and long-term if directed towards deepening the role of physical capital by providing new technology in the form of productive capital projects and infrastructure projects that stimulate domestic and foreign investment. These effects are strengthened further by enhancing absorptive capacity (knowledge, skills, and experience) through technical assistance and expenditures directed at education, training, and health.

In terms of previous studies that dealt with the issue of the relationship between external grants and economic growth, Irandoust \& Ericsson (2005) concluded that foreign aid stimulated and increased economic growth in a sample of African countries, that included Nigeria, Niger, Togo, Rwanda, and Senegal. Muhammad \& Qayyum (2011) stated that grants and aids contributed to establishing infrastructure and obtaining technology, which raised the production capacity in various productive sectors in Pakistan. In the same field, Karras (2006) showed that the effect of foreign aid on economic growthwas significant and positive,for a sample of 71 aid-recipient developing countries. The study conducted by the Arab Center for Planning (2011) showed that official development aid is still marginal, if not non-existent, in improving the level of human development as an indicator of poverty. Samara \& Nader (2013) also indicated that foreign aid positively affectedgrowth, and foreign aid wasthe most important means of financing the budget deficit and the expenditures of the Palestinian Authority, and at the same time, foreign aid createdan economic and political dependency on the outside, which is political aid par excellence according to the vision of donor countries. Djankov \& Reynal-Querol (2006) revealed that the grants had no effect on investment and growth, while they had a positive effect on government consumption spending because they are easy resource for the recipient countries, and are ineffectively exploited and directed to rentier activities and serve political interests.

We note the inconsistency in the results of previous studies on the effects of international financial flows on economic growth, which leads us to conclude that no definitive opinion can be observed as to the effectiveness of the effects of international financial flows on economic growth. This view can 
INTERNATIONAL JOURNAL OF ACADEMIC RESEARCH IN ACCOUNTING, FINANCE AND MANAGEMENT SCIENCES

Vol. 11, No. 1, 2021, E-ISSN: 2225-8329 @ 2021 HRMARS

be attributed to the difference in the data related to each country, and the difference in the statistical methodology and period in the previous studies. Hence, the importance of this study emerges because the inconsistency in the results constitutes an incentive to re-examine this issue repeatedly, using modern time series and various statistical methods to ascertain the effects of international financial flows on economic growth. If a limited or undesirable effect of the flows is found, it would require reconsideration of dealing with them in a way that serves the economic activity of the state and makes it less vulnerable to regional and international fluctuations and crises.

\section{Study Variables Developments Development of the GDP in Jordan}

Figure (1) shows the remarkable improvement in the Jordanian GDP during the study period, as the estimates of the GDP (issued by the Central Bank of Jordan) indicated that the GDP at current market prices for the year 2019 reached (31597) million dinars, compared to (5998.6) one million dinars for the year 2000, showing a growth rate of about (427\%). Growth rates for the GDP had positive results during the study period, which may bebecause of the growth of various economic sectors in Jordan, despite the difficult regional and international conditions that prevailed in the region, such as the war in Iraq, the civil war in Syria, and the resulting refugee crisis, as well as the continuing worsening of the situation in the Palestinian territories, in addition to the exacerbation of the debt crisis and the continuous fluctuations in exports, remittances of overseas workers, foreign direct investment, and external grants.

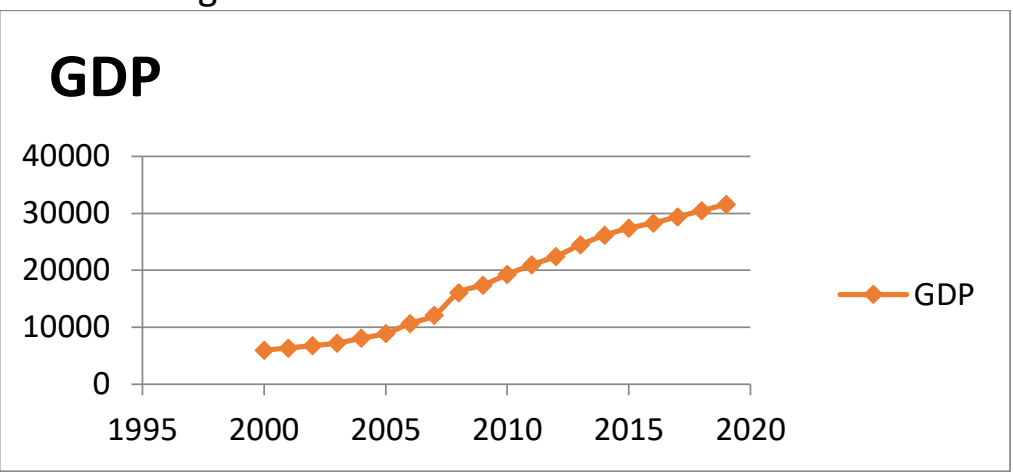

Figure (1): Development of GDP during the period (2000-2019)

\section{Development of Jordanian Exports}

Figure (2) shows that the volume of Jordanian exports has doubled to record an increase from 1080.8 million dinars in 20004992.1 million dinarsin 2019 , with a growth rate of $461 \%$. The figure also shows that the volume of exports witnessed a growth in all the years of the study, except for the years 2016, 2015, 2012, and 2009, whichwitnessed a decline. Figure (3) indicates that the contribution of exports to the GDP reached $21 \%$ on average during the study period, and thus had the largest contribution to the GDP among the study variables, thereby indicating the role that exports can play in contributing to the growth of output and the registration of higher economic growth rates for the Jordanian state. 


\section{EX}

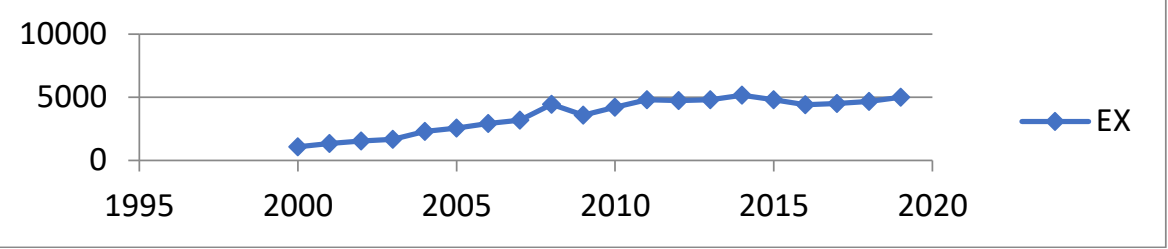

Figure (2): Development during the period (2000-2019)

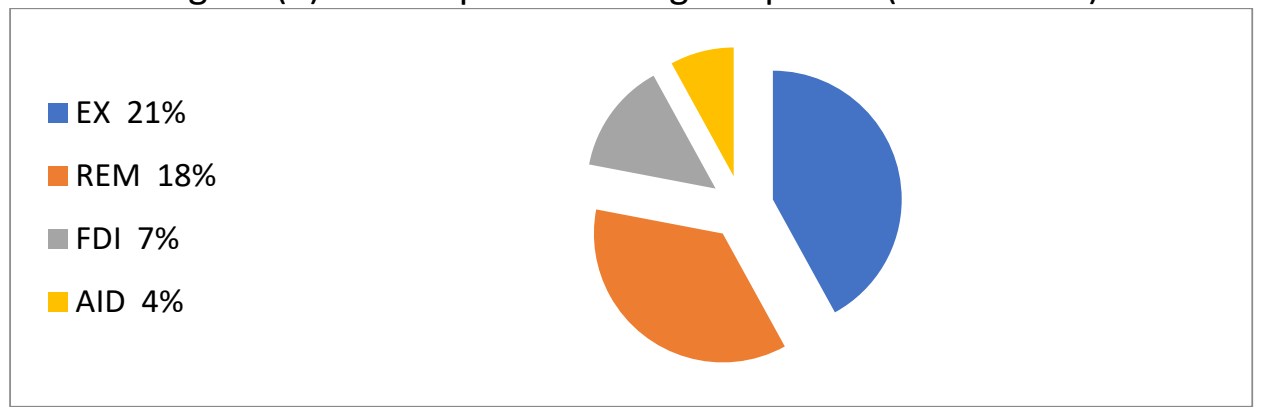

Figure (3): International financial flows as a percentage of GDP during the period (2000-2019)

\section{Development of Jordanian Workers' Remittances Abroad}

Figure (4 shows the continuous increase in the volume of remittance flows of Jordanian workers abroad from the beginning of the study until the year 2015. In2000, it reached (1548.4) million Jordanian dinars, then jumped to about 5161million Jordanian dinars, then declined. It reached 3434.8 million Jordanian dinars in 2019. It is important to point out the relative importance of this type of financial flows to the GDP, which reached (18\%) on average during the study period, as shown in Figure (3). Moreover, they are the most stable types of flows for Jordan. Its size exceeds the external grants and foreign direct investment and keeps pace with exports, which implies that the economic benefit of remittances is as important as the importance of exports.

\section{REM}

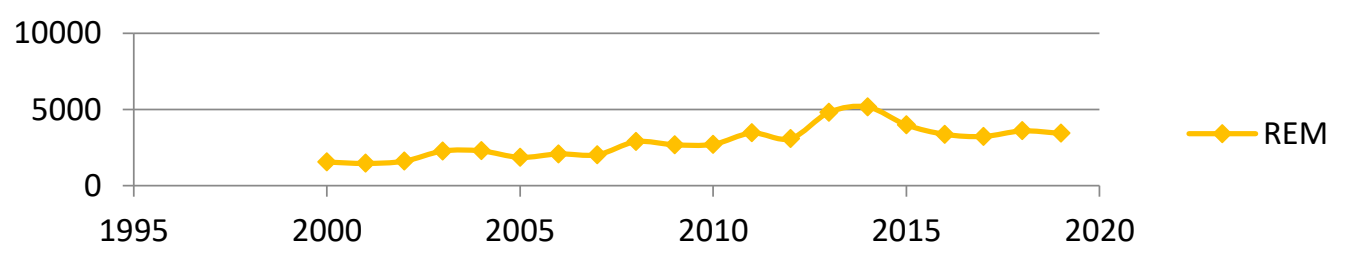

Figure (4): Development of workers' remittances abroad during the period (2000-2019)

\section{Development of Foreign Investment in Jordan}

Despite the continuous efforts made by the Jordanian government by issuing laws that create the appropriate environment to attract and encourage foreign investments, the volume of foreign direct investment in Jordan remains modest as compared to the size of workers'remittances abroad and the volume of exports. Figure 5 shows the general trend of foreign direct investment was increasing in the period of (2000-2006) and decreasing during the period (2007-2019), and which could be due to the developments in the region, in addition to the prevailing economic and political situation in 
INTERNATIONAL JOURNAL OF ACADEMIC RESEARCH IN ACCOUNTING, FINANCE AND

MANAGEMENT SCIENCES

Vol. 11, No. 1, 2021, E-ISSN: 2225-8329 @ 2021 HRMARS

the region. Jordan. This fluctuation in foreign direct investment towards Jordan was reflected in the low percentage of its contribution to the GDP, which amounted to an average of $7 \%$.

\section{FDI}

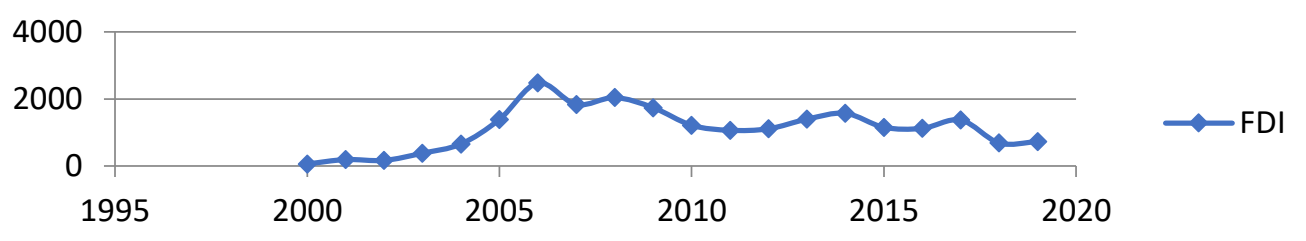

Figure (5): Development of foreign direct investment during the period (2000-2019)

\section{Development of External Grants in Jordan}

The Jordanian state receives external grants from Arab and foreign sources, and Jordan gets the bulk of these grants from some major donors, including Saudi Arabia, the Emirates, Kuwait, Qatar, America, the European Union, and Japan. A fluctuation was observed in these grants throughout the study period, The volatility is because the provision of these grants is governed by the political and economic conditions that prevail in the region surrounding Jordan. Figure (6) shows that the highest level of these grants was in 2014 at 1236.5 million Jordanian dinars. However, the sums transferred from the Gulf grant, amounting to 1661 million dinars, provided by the Kingdom of Saudi Arabia, the United Arab Emirates, and Kuwait to Jordan during the years 2012-2016 are the most important aid that came to Jordan out of about 3500 million dinars. It was approved by the Supreme Council of the Cooperation Council for the Arab States of the Gulf for the years 2012-2017. As for the relative importance of external grants from the gross domestic product, their contribution was weak during the study period, reaching an average of $4 \%$.

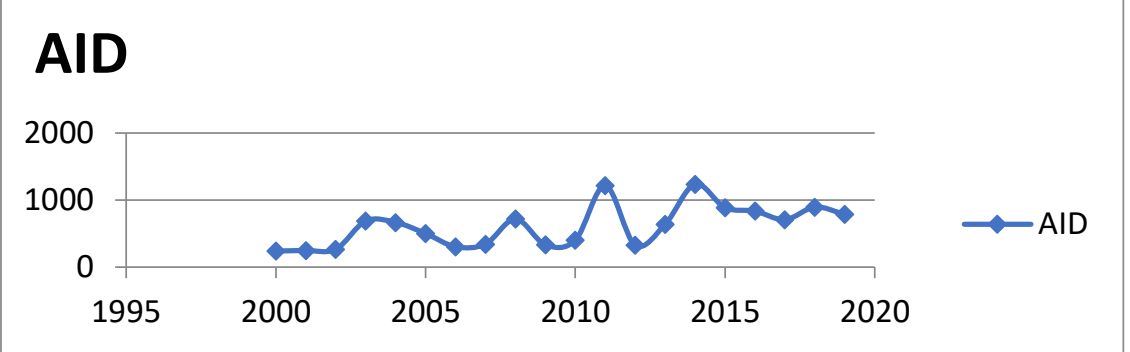

Figure (6): Development of external grants during the period (2000-2019)

\section{Study Methodology and Standard Model Used Study Methodology}

The study adopted descriptive and analytical approach to review international financial flows represented in exports, remittances of overseas workers, foreign investment, external grants and economic growth of the Jordanian state to answer the problem of the study and achieve its objectives. The study also adopted the descriptive statistical approach when exploringthe nature of the relationship between the study variables in the short and long term during the period (2000_2019) through the testing the bounds approach. The approach usesthe self-regression of the distributed slowdown periods or theautoregressive distributedlag ( $A R D L$ ), which requires running time-series static tests to ensure they are still at the level or at the first difference, which is the 
INTERNATIONAL JOURNAL OF ACADEMIC RESEARCH IN ACCOUNTING, FINANCE AND

MANAGEMENT SCIENCES

Vol. 11, No. 1, 2021, E-ISSN: 2225-8329 @ 2021 HRMARS

premise on which the boundary testing methodology is applied. This methodology in measuring the co-integration (long-term equilibrium relationship between variables) is characterized by being appropriate in the case of the small number of observations and the difference in the order of integration of the variables.

For data collection, the researcher relied on collecting data related to the gross domestic product, exports, and external grants from statistical data issued by the Central Bank of Jordan. For the data related to workers' remittances abroad and foreign direct investment, the researcher relied on statistical data issued by the World Bank database.

\section{Standard form Used}

This study will mainly depend on the model on which most previous studies have relied to prove that international financial flows have a significant effect on economic growth in Jordan. This study will use a model of six variables, specifically the gross domestic product (GDP) as a dependent variable representing economic growth. Assuming that it is a function of exports, remittances of overseas workers, foreign direct investment, and external grants, the model isshown by using the mathematical function as follows:

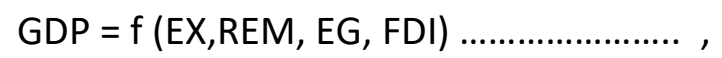

where

GDP: Gross domestic product based on current prices.

EX: Exports. Its predicted sign is positive.

REM: Workers remittances abroad. Its predicted sign is positive.

EG: External grants. Its predicted sign is positive.

FDI: Foreign Direct Investment. Its expected sign is positive.

The value of these variables is measured in Jordanian dinars. It was taken from the statistics of the Central Bank of Jordan, the World Bank database, and through the bank's website.

To know the appropriate mathematical formula for estimating the study model, the researcher will use the mathematical formula for the equations of the linear model, where the best results were obtained using the growth rates of the study variables. The mathematical formula of the model is as follows:

$$
\mathrm{GDP}=\alpha+\beta 1 \mathrm{GEXt}+\beta 2 \mathrm{GREMt}+\beta 3 \mathrm{GFDIt}+\beta 4 \mathrm{GEGt}+\varepsilon
$$

where:

GGDP: GDP growth rate based on current prices.

GEX: rate of export growth.

GREM: Growth rate of workers' remittances abroad.

GFDI: Foreign Direct Investment Growth Rate.

GEG: External Grant Growth Rate.

$\alpha$ : represents the constant term.

$\mathrm{t}$ : denotes periods.

$\varepsilon$ : the term error of the equation that must be added to the model to represent the rest of the variables that affect the model and were not included for specific reasons.

$\beta 1, \beta 2, \beta 3, \beta 4$ : Represent the model parameters. 
INTERNATIONAL JOURNAL OF ACADEMIC RESEARCH IN ACCOUNTING, FINANCE AND

MANAGEMENT SCIENCES

Vol. 11, No. 1, 2021, E-ISSN: 2225-8329 @ 2021 HRMARS

\section{Analyzing and Discussing the Results of the Standard Study Stationary Test (Unit Root Test) ADF}

The first stage of statistical analysis is to test the stability or instability of variables in the short term, that is, to detect whether the time series are stable or unstable at their levels or when calculating their first differences, because the stability condition is essential in studying and analyzing the time series and identifying the results of the analysis (Gujarati \& Porter, 2009). One of the most common tests for detecting the presence of the unit root in the time series data, which will be used in this study, is the AugmentedDickey-Fuller (ADF) test. The stability of the variables is judged by the probability, tabular, and computed values. By applying the test, the results presented in Table (1) were obtained.

Table (1) Results of Stability of Time series test (Unit Root Test)

\begin{tabular}{|l|l|l|l|c|c|}
\hline \multirow{2}{*}{ Variable } & \multicolumn{2}{|c|}{ Level } & & \multicolumn{2}{c|}{ First deference } \\
\cline { 2 - 6 } & \multicolumn{1}{|c|}{$\begin{array}{c}\text { ADF } \\
\text { statistics }\end{array}$} & \multicolumn{1}{c|}{ Prob } & Result & $\begin{array}{c}\text { ADF } \\
\text { statistics }\end{array}$ & Result \\
\hline GGDP & $-8.383500^{*}$ & 0.000 & Non & -8.383500 & Stationary \\
\hline GEX & $-6.622963^{*}$ & 0.0002 & Stationary & - & - \\
\hline GREM & $-4.411106^{*}$ & 0.0002 & Stationary & - & - \\
\hline GAID & $-5.437230 *$ & 0.0004 & Stationary & - & - \\
\hline GFDI & $-6.046609 *$ & 0.0007 & Stationary & - & - \\
\hline
\end{tabular}

*: stable at a significant level (1\%).

Source: Author's representation using EViews 9 program.

The results in Table (1) show that all the independent variables (GEX, GREM, GAID, GFDI) are stable at the level, and that is at a slowdown period (3), where the absolute values calculated for DAF were greater than the absolute values of the theoretical Mackinnon values at the significance level of $1 \%$. Therefore, we reject the null hypothesis and accept the alternative hypothesis no unity root can be found in the series of these variables. As for the dependent variable (GGDP), it was not stable at the level, however, after taking the first difference to get remove unit root, it was found that the variable had become stable at a significant level (1\%).

\section{Bounds Testing Approach}

Due to the different degrees of stability of the study variables, the ARDL methodology is best suited for conducting the co-integration test. As for the other co-integration methodologies, it is not possible to use them because they require that the variables be induced at the same degree of stability (Pesaran et al. 2001).

The ARDL approach is used to test the extent of a long-term equilibrium relationship between the dependent and the independent variables included in the model, as its (F) statistic is calculated to 
INTERNATIONAL JOURNAL OF ACADEMIC RESEARCH IN ACCOUNTING, FINANCE AND MANAGEMENT SCIENCES

Vol. 11, No. 1, 2021, E-ISSN: 2225-8329 @ 2021 HRMARS

test the null hypothesis $(\mathrm{HO})$, which states that all the parameters of the slowing independent variables for one period are equal to zero, meaning that

$$
(\mathrm{HO}: \mathrm{b} 1=\mathrm{b} 2=\mathrm{b} 3=\mathrm{b} 4=\ldots .=\mathrm{bk}+1=0)
$$

The absence of a long-term equilibrium relationship between the variables (the lack of co-integration between variables) as opposed to the alternative hypothesis $(\mathrm{H} 1)$ which states that the parameters of the slowing variables are not equal to zero, means

$$
(H 1: b 1 \neq b 2 \neq b 3 \neq b 4 \neq \ldots . \neq b k+1 \neq 0)
$$

in the sense that a long-term equilibrium relationship exists between the variables (the existence of co-integration between the variables).

After extracting a statistic value (F) and comparing it to the tabular value of $(F)$ computed by Pesaran et al (2001), and because the (F) test has a non-standard distribution, it has two critical values for it, the first is the minimum value and it assumes that all variables are static in their values The original (i.e. at its level), meaning that it is an integral of the zero-order I (0), and the second is the value of the upper bound and assumes that all the variables are static in their first difference, meaning they are integral from the rank one integer I (1). If the calculated value of (F) statistic is greater than the upper limit of the tabular $(F)$, then the null hypothesis which states that no co-integration exists between the variables is rejected and the alternative hypothesis states that a covariance relationship between the variables is accepted. But if the calculated value of (F) statistic is smaller than the minimum table value of $(F)$, then the alternative hypothesis that states that there is a common complement between the variables cannot be accepted, and the null hypothesis is accepted, i.e. the absence of a common integration between the variables. If the calculated value of $(F)$ falls between the upper and lower limits, the results are inconclusive, and this means the inability to decide to determine whether a common complementarity exists between the variables (Driouche \& Abdelkader, 2014).

Table (2) shows that the calculated F value of (5.855307) is greater than the value of the upper limit of (5.06) at the $1 \%$ level of significance, which means the null hypothesis $(\mathrm{HO}: \mathrm{b} 1=\mathrm{b} 2=\mathrm{b} 3=\mathrm{b} 4)$ is rejected and the alternative hypothesis ( $\mathrm{H} 1: \mathrm{b} 1 \mathrm{~b} 2 \neq \mathrm{b} 3 \neq \mathrm{b} 4)$ is accepted. Thus, long-term equilibrium relationship between the variables of international financial flows represented in exports, remittances of overseas workers, foreign direct investment, external grants, and economic growth exists along with a joint complementarity relationship between study model variables. 
INTERNATIONAL JOURNAL OF ACADEMIC RESEARCH IN ACCOUNTING, FINANCE AND MANAGEMENT SCIENCES

Vol. 11, No. 1, 2021, E-ISSN: 2225-8329 @ 2021 HRMARS

Table (2) Joint integration testing, using the ( ARDL Bounds Test)

\begin{tabular}{lll}
\hline \hline Test Statistic & Value & $\mathrm{k}$ \\
\hline \hline F-statistic & 5.855307 & 4 \\
\hline \hline
\end{tabular}

Critical Value Bounds

\begin{tabular}{lcc}
\hline \hline Significance & I0 Bound & I1 Bound \\
\hline \hline $10 \%$ & 2.45 & 3.52 \\
$5 \%$ & 2.86 & 4.01 \\
$2.5 \%$ & 3.25 & 4.49 \\
$1 \%$ & 3.74 & 5.06 \\
\hline \hline
\end{tabular}

Source: Author's representation using EViews 9 program.

\section{Estimating Model Parameters Long and Short-term and the Error Correction Parameter}

After ensuring the existence of a long-term equilibrium relationship between the independent variable, international financial flows, represented in the model and the dependent variable, economic growth, the parameters of the long and short-term ARDL model and the vector parameter ECM were estimated based on the number of slowdown periods specified according to the test period criteria slow down and for all variables. At this stage, the Hendry method is used from general to specific (Thanoon \& Jarallah, 2013, 39), and involves an estimate that includes the use of slowers for the time series of the variables included in the model along with the error correction limit (ECM). Tables (3) and (4) show the results of these estimates. 
INTERNATIONAL JOURNAL OF ACADEMIC RESEARCH IN ACCOUNTING, FINANCE AND MANAGEMENT SCIENCES

Vol. 11, No. 1, 2021, E-ISSN: 2225-8329 @ 2021 HRMARS

Table (3) Long-term coefficients

\begin{tabular}{ccccc}
\hline \hline Variable & Coefficient & Std. Error & t-Statistic & Prob. \\
\hline GEX & 0.462381 & 0.187634 & 2.464264 & 0.0488 \\
GREM & -0.525757 & 0.231590 & -2.270205 & 0.0636 \\
GAID & 0.277893 & 0.101910 & 2.726851 & 0.0343 \\
GFDI & 0.031049 & 0.039746 & 0.781183 & 0.4644 \\
C & 0.034190 & 0.022366 & 1.528629 & 0.1772 \\
\hline \hline & & & & \\
\hline \hline R-squared & 0.957564 & Mean dependent var & 0.098761 \\
Adjusted R-squared & 0.893909 & S.D. dependent var & 0.074431 \\
S.E. of regression & 0.024243 & Akaike info criterion & -4.332180 \\
Sum squared resid & 0.003526 & Schwarz criterion & -3.849312 \\
Log-likelihood & 44.65744 & Hannan-Quinn criter. & -4.307453 \\
F-statistic & 15.04313 & Durbin-Watson stat & 1.965630 \\
Prob(F-statistic) & 0.001830 & & \\
\hline \hline
\end{tabular}

Source: Author's representation using EViews 9 program.

The table shows that the variables selected based on the economic theory explains the magnitude of the changes in Jordanian economic growth. Some of the variables have apositive sign, and others have a negative sign. From the results of estimating the above table, the ECM equation will take the following form:

Cointeq = GGDP $-(0.4624 *$ GEX $-0.5258 *$ GREM + 0.2779*GAID+ $0.0310 *$ GFDI + 0.0342) . Table (4) ARDL Co-integrating and Short-term Form

\begin{tabular}{crrrr}
\hline \hline \multicolumn{5}{c}{ Cointegrating Form } \\
\hline \hline Variable & Coefficient & Std. Error & t-Statistic & Prob. \\
\hline \hline D(GGDP(-1)) & 0.576120 & 0.208793 & 2.759286 & 0.0329 \\
D(GGDP(-2)) & 0.827962 & 0.220078 & 3.762128 & 0.0094 \\
D(GEX) & 0.235639 & 0.070905 & 3.323327 & 0.0159 \\
D(GREM) & 0.018562 & 0.052639 & 0.352625 & 0.7364 \\
D(GAID) & 0.076707 & 0.028952 & 2.649443 & 0.0381 \\
D(GFDI) & 0.015823 & 0.019174 & 0.825254 & 0.4408 \\
CointEq(-1) & -0.509621 & 0.129988 & -3.920520 & 0.0078 \\
\hline \hline
\end{tabular}

Source: Author's representation using EViews 9 program.

From the results of the above table, it is clear that the estimates of the short and long term parameters correspond to a large extent in terms of the level of significance and signals, and that 
INTERNATIONAL JOURNAL OF ACADEMIC RESEARCH IN ACCOUNTING, FINANCE AND

MANAGEMENT SCIENCES

Vol. 11, No. 1, 2021, E-ISSN: 2225-8329 @ 2021 HRMARS

the values of the parameters differedin varying proportions except for the variable (GREM), the signal of which became negative and significant at the level of $10 \%$ in the long term.

\section{Evaluating the Economically and Statistically Estimated Model}

First: Evaluation of the Economically Estimated Model

\section{Evaluation of the Capabilities of the Model Parameters in the Long and Short Term}

-The GEX coefficient indicates the existence of a statistically significant positive effect of exports on economic growth in the long and short term. Exports by $1 \%$ will lead to an increase in economic growth by $0.462381 \%$ and $0.235639 \%$ in the long and short term, respectively.

- The GREM coefficient indicates the existence of a statistically significant negative effectof remittances of overseas workers on economic growth in the long term, and positive and nonsignificant in the short term. The long term, 0.018562 in the short term, meansan increase in remittances of overseas workers by $1 \%$ will lead to a decrease in economic growth by $-0.525757 \%$ in the long term, and an increase in economic growth by $0.018562 \%$ in the short term.

- The GAID coefficient indicates the existence of a statistically significant (significant) positive effect of external grants on economic growth in the long and short term. The partial elasticity of external grants for economic growth reached 0.277893 in the long term and 0.076707 in the short term, which means an increase in external grants by $1 \%$ will lead to an increase in economic growth by $0.277893 \%$ and $0.076707 \%$ in the long and short term, respectively.

- The GFDI coefficient indicates the existence of a weak and insignificant positive effect of foreign direct investment on economic growth in the long and short terms. Foreign direct investment by $1 \%$ will lead to an increase in economic growth by $0.031049 \%$ and $0.015823 \%$ in the long and short term, respectively.

\section{Estimation of Capabilities of the Unrestricted Error Correction Model (ARDL-VECM)}

It is evident through the results of the estimates of the short-term model parameters shown in Table (4) that the value of the error correction factor (Coint Eq (-1)) in the economic growth equation, which is about -0.51 , was significant and negative, at the $1 \%$ significance level. It provides evidence of the existence of a long-term equilibrium relationship between international financial flows and economic growth, and that the error correction speed of -0.51 means that the imbalance in the longterm equilibrium is corrected at an adjustment speed of $51 \%$.

\section{Second: Evaluating the Statistically Estimated Model}

Concerning the statistical indicators, the short and long-term parameters were significant for exports and external grants according to the $(t)$ test, while the parameter estimated for workers'remittances abroad was significant in the long term and was not significant in the short term, but the foreign direct investment parameter was not significant in the short and long term. In addition, the value of the corrected coefficient of determination (Adjusted $\mathrm{R}^{2}$ ) reached $89 \%$, which indicates the quality of the projected model, that the independent variables represented in the model explain a large proportion of the behavior of the dependent variable of economic growth, and that the standard error of the model was very limited at 0.024243 . The (F) test was also statistically significant at the 1\% significance level (15.04313), which confirms the significance of the estimated model as a whole. As for the problem of autocorrelation, the value of DWstatistically approaches2at approximately 
INTERNATIONAL JOURNAL OF ACADEMIC RESEARCH IN ACCOUNTING, FINANCE AND MANAGEMENT SCIENCES

Vol. 11, No. 1, 2021, E-ISSN: 2225-8329 @ 2021 HRMARS

1.97, which indicates that the estimated model is devoid of the self-correlation problem of the random error limit.

\section{Structural Stability Test for Model Transactions (UECM - ARDL)}

The cumulative sum of recursive residual (CUSUM) test is used to test the structural stability of long and short-term transactions (Al Abdali, 2014, 261). According to this test, the structural stability of the parameters estimated in the ERDL model is achieved when the CUSUM is confined within the critical graphic lines atthe $5 \%$ significance level. Meanwhile, if the graphic line is outside the critical graphic lines at the $5 \%$ significance level,then the transactions are not stable.

Figure (7) shows that the CUSUM statistic line is confined within the critical graphic lines at the $5 \%$ significance level, which means the model estimates between the long-term results and the shortterm results are stable and that the estimated coefficients of the error correction model, the unrestrained (CUSUM)user, is structurally stable during the study period.

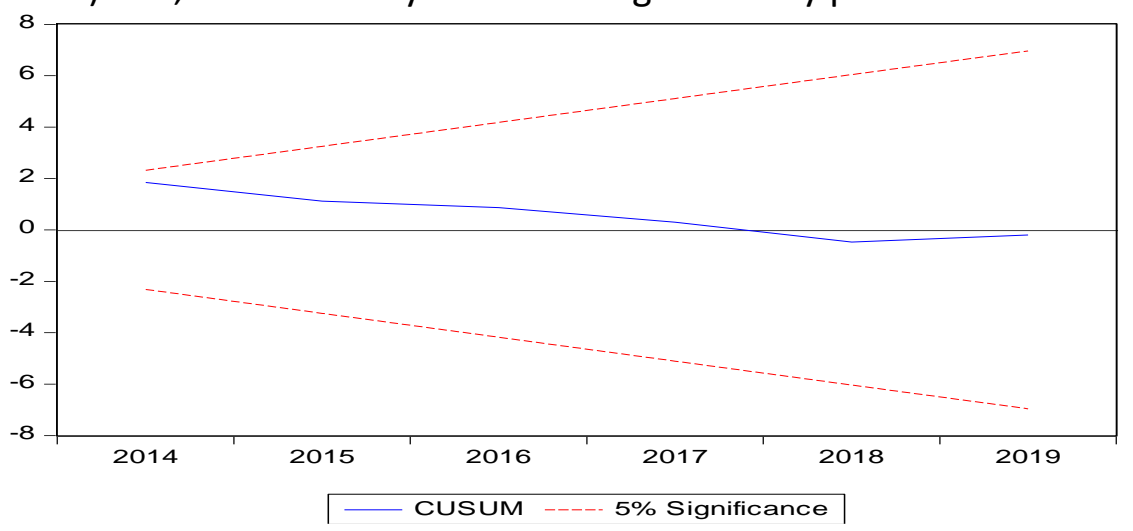

Figure (7) Stability test of the (CUSUM) model

Source: Author's representation using EViews 9 program.

\section{Predictive Performance Testing of the Estimated Unrestricted Error Correction Model}

The quality of the estimated results depends on the strength of the predictive performance of the unrestricted error correction model, and this, the model must have a good ability to predict during the period of the estimation. Thus, to test the model's ability to predict, Thiel's Coefficient, which is one of the most important measures of the predictive performance of the models, was used. If the value of Thiel's Coefficient is equal to or close to zero, it indicates that themodel's great ability to predict, whereas if the value of this coefficient is equal to one integer, then the dependent variable will be constant over time, and if its value is greater than one, it indicates the low ability of the model to predict and the criterion of inequality ratio (source of error), which consists of three ratios, namely, covariance proportion, variance proportion, and bias proportion (Bakr and Sharafuddin, 2014, 37) The figure shows that the Thiel's Coefficient is equal to 0.11 , which is low and close to zero, and the ratios of variance proportion and bias proportion were also close to zero $(0.012471$ and 0.069949 , respectively). The value of the covariance proportion is equal to 0.917580 , which is close to one true. It follows from these results that the unrestricted error correction model used has a high capacity for interpolation during the study period. Figure 8 also shows the behavior of economic growth according to the estimated standard model, and accordingly, the results of this model can be relied upon for analysis, policy evaluation, forecasting, and decision-making related to economic affairs. 
INTERNATIONAL JOURNAL OF ACADEMIC RESEARCH IN ACCOUNTING, FINANCE AND MANAGEMENT SCIENCES

Vol. 11 , No. 1, 2021, E-ISSN: 2225-8329 @ 2021 HRMARS

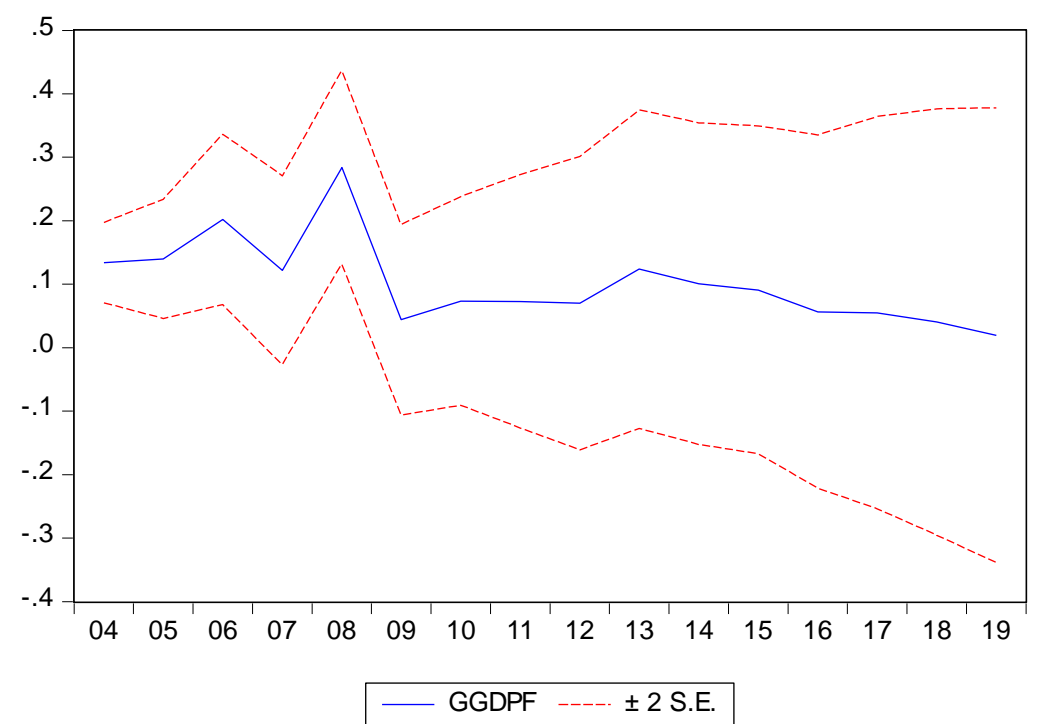

Forecast: GGDPF

Actual: GGDP

Forecast sample: 20012019

Adjusted sample: 20042019

Included observations: 16

Root Mean Squared Error $\quad 0.026855$

Mean Absolute Error $\quad 0.023203$

Mean Abs. Percent Error 32.20892

Theil Inequality Coefficient 0.110518

Bias Proportion $\quad 0.012471$

Variance Proportion $\quad 0.069949$

Covariance Proportion $\quad 0.917580$

Figure 8. Testing the forecasting ability of the model

Source: Author's representation using E-view program.

\section{Results}

- The volatility in GDP growth because of the effects of the nature of economic and political conditions and the changes in fiscal policy that accompanied the course of the economy during the study period(2000-2019) was observed.

- The contribution of exports to the GDP amounted to21\% on average during the study period, which is the largest contribution to the GDP among the variables of international financial flows included in the study.

- Remittances of Jordanian workers are the most stable type of flows for Jordan, and their volume exceededtheexternal grants and foreign direct investment. Theircontribution to the gross domestic product reached $18 \%$ on average during the study period.

- The volume of foreign direct investment in Jordan is still modest compared to the size of remittances of overseas workers and the volume of exports. Its contribution to the GDP amounted to $7 \%$ on average during the study period, which may bebecause of the developments the region is going through, in addition to the prevailing economic and political situation in Jordan.

- The sharp fluctuation of external grants offered to Jordan, because of their connection to different dates and their connection to events in the Middle East region, as well as the political stances of the Jordanian state represent a tool to pressure Jordan to align with the political positions of the donor countries.

- Based on the unit root test (ADF), all independent variables GEX, GREM, GAID, and GFDI were found to be stable at the level and a significant level (1\%). For dependent variable (GGDP), it was not stable at the level, and after taking the first difference, it was found that the variable had become stable at a significant level (1\%).

- Using the border test approach, the existence of a long-term equilibrium relationship between the variables of international financial flows and economic growth was identified, 
which validated the existence of a common complementarity relationship between the variables of the study model.

- The existence of a positive, statistically significant effect of exports on economic growth in the long and short term. This result is consistent with some previous studies, such as Behnam 2019, Miloud and Muhammad \& Qayyum, 2011, and Alraimony, 2011.

- The existence of a statistically significant negative effect of remittances from workers abroad on economic growth in the long term, and the existence of a positive non-significant effect in the short term. This result is consistent with the study (Karagoz 2009). Perhaps the reason for this is that most workers'remittances are directed at the demand for consumer imports and that a small part of them are employed in productive investment activities, which leads to a reduction in their role in economic growth.

- The existence of a positive, statistically significant effect of external grants on economic growth in the long and short term. This result is consistent with some previous studies, such as Irandoust \& Ericsson 2005 and Karras, 2006.

- A weak and insignificant positive effect of foreign direct investment on economic growth in the long and short term was observed. This result is consistent with the example of Rahman (2015).

- The value of Adjusted $\mathrm{R}^{2}$, which amounted to $89 \%$, shows the quality of the estimated model. This resultindicates that the independent variables represented in the model explain a large proportion of the behavior of the dependent variable on economic growth.

\section{Recommendations}

- The Jordanian government needs to adopt a policy of encouraging exports that would increase the share of total exports and its positive contribution to the gross domestic product by setting up a national strategy for exports through the introduction of national exportable products, exploration ofpotential markets, and the improvement of the quality of Jordanian products to ensure their success. The creation of new products capable of entering foreign markets and the state's contribution to providing financial support to exporters is also necessary.

- Given the positive effects of remittances from Jordanians abroad on economic growth, the study recommends the adoption of the Jordanian government of policies that enable the remittances to be used for investment purposes instead of spending them for consumer purposes, facilitate Jordanian workers to work in foreign markets and mitigate shocks that may result from the decline in the remittances of workers, including the establishment of a fund for this purpose.

- The Jordanian government should also formulate policies directed at foreign direct investment by conducting a periodic review of the institutional and legal frameworks concerned with encouraging investment in Jordan, addressing bureaucratic procedures, bribery, and corruption, and adopting a promotional strategy to introduce environment and investment advantages available in Jordan.

- Given the sharp fluctuation of external grants provided to Jordan, the Jordanian government must manage the negotiation process with donors well and search for new donors. Reliance on certain countries is a matter of concern for the long-term stability of the Jordanian 
INTERNATIONAL JOURNAL OF ACADEMIC RESEARCH IN ACCOUNTING, FINANCE AND

MANAGEMENT SCIENCES

Vol. 11, No. 1, 2021, E-ISSN: 2225-8329 @ 2021 HRMARS

economy becauseit has resulted in political dependence on those countries on several issues and on directing grants towards priority projects for the Jordanian economy.

- The study recommends conducting in-depth future studies on the international financial flows of Jordan and their various economic effects because this issue is of great importance to the Jordanian economy.

Contribution: This study is going to be one of very few studies that have investigated International Financial flows its Effects on Economic Growth in Jordan where economy relies heavily on external grants and remittances. This study will therefore prove a scientific addition to the field of financial and economic research.

\section{References}

Al Abdali, S. A. (2014). Measuring and Analyzing of the Relationship between the Financial Development, Economic growth, and Poverty in Iraq with the Autoregressive Distributed lag Model framework for the period (1980-2010), Journal of Economics And Administrative Sciences,20, (77), 261

Adusah-Poku, F. (2016). Which Form of Foreign Capital Inflows enhance economic growth? Empirical evidence in Sub-Saharan Africa. Asian Economic and Financial Review, 6, (10),pp557-570.

Al kousini, E., \& Shawaqfeh, W. (2020). Components of International Finance and Its Impact on Economic Growth in Jordan (1979-2015), Jordan Journal of Economic Sciences, 7(1), 73-89.

Al raimony, A. (2011). The Determinants of Economic Growth in Jordan, Abhath Al-Yarmouk, Humanities, and Social Sciences Series, 27(3): 2297-2305.

Al Sawai, Kh., M. (2005). Trade and Development, Dar Al-Manahej, First Edition, Jordan, 38

Athamneh, A. B., \& Zubi, B. (2008). The Long-run Macroeconomic Impact of Labor Migration: An Econometric Analysis for the Case of Jordan 1973-2004. DIRASAT (Administrative Sciences), 35(2).

Badreldin, A. (2018). Impact of Exports on Economic Development in Sudan: An Econometric Study, 1990-2016. El-Bahith Review. 18 (18), 109-119.

Bakari, S. (2017). The Long Run and Short-Run Impacts of Exports on Economic Growth: Evidence from Gabon. Munich Personal RePEc Archive, No. 79871(June 2017).

Behnam, S. H. (2019). Export Development Policy and its Impact on Economic Growth in Malaysia Period (1990-2014). TANMIYAT AL-RAFIDAIN, 38(122), 139-154.

Bourahla, M., \& Boutouba, M. (2013). The Impact of Exports on Economic Growth in Algeria during the Period (1990-2013), Analytical Standard Study11(13), 201-220.

Chowdhury, A., \& Mavrotas, G. (2003). FDI and growth: what causes what?. World economy, 29(1), 9-19.

access world bank databases://databank.worldbank.org/home.aspx

Djankov, S., Montalvo, J. G., \& Reynal-Querol, M. (2006). Does foreign aid help. Cato J., 26, 1. ,1-28.

Driouche, D. M., \& Abdelkader, N. (2014). Macroeconomic Determinants of Foreign Direct Investment in Algeria: An Econometric Study using ARDL Bounds Testing Approach Of Cointegration, Scientific Journal of Research and Business Studies, Helwan University, Cairo, Egypt, 4( 1). 18

Gujarati, D. N., \& Porter, D. C. (2009), Basic Econometrics, 5th ed., New York, McGraw-Hill Companies, Inc. 
INTERNATIONAL JOURNAL OF ACADEMIC RESEARCH IN ACCOUNTING, FINANCE AND

MANAGEMENT SCIENCES

Vol. 11, No. 1, 2021, E-ISSN: 2225-8329 @ 2021 HRMARS

Hussein, M. A. (2009). Impacts of foreign direct investment on economic growth in the Gulf Cooperation Council (GCC) Countries. International Review of Business Research Papers, 5(3), 362-376.

Insah, B. (2013). "Foreign direct investment inflows and economic growth in Ghana,International Journal of Economic Practices and Theories 3(2),115-117.

Irandoust, M., \& Ericsson, J. (2005). Foreign aid, domestic savings, and growth in LDCs: An application of likelihood-based panel cointegration. Economic Modelling, 22(4), 616-627.

Jawaid, S. T., \& Raza, S. A. (2012). Workers' remittances and economic growth in China and Korea: anempirical analysis. Journal of Chinese Economic and Foreign Trade Studies, 5(3), 185-193.

Karagoz, K. (2009). Workers' remittances and economic growth: evidence from Turkey. Journal of Yasar University, 4(13). pp1891-908. Retrieved from http://journal.yasar.edu.tr/wpcontent/uploads/2012/05/no13_vol4_01_karagoz.pdf.

Karras, G. (2006). Foreign Aid and Long-Run Economic Growth: Empirical Evidence for a Panel of Developing Countries. Journal of International Development, 18(1),15-28

Mendoza-Cota, J. E. (2017). Exports and economic growth in Mexico, 2007-2014: A panel cointegration approach. Semestre económico, 20(44), 19-44.

Muhammad, J., \& Qayyum, A. (2011). Foreign aid-growth nexus in Pakistan: role of macroeconomic policies.

Onu, A. J. C. (2012). Impact of foreign direct investment on economic growth in Nigeria. Interdisciplinary Journal of Contemporary Research in Business, 4(5), 64-79.

Pesaran, M. H., Shin, Y., \& Smith, R. J. (2001). Bounds testing approaches to the analysis of level relationships. Journal of applied econometrics, 16(3), 289-326.

Rahman, A. (2015). Impact of foreign direct investment on economic growth: Empirical evidence from Bangladesh. International Journal of Economics and Finance, 7(2), 178-185. https://www.researchgate.net/publication/269399741 Impact of Foreign Dirt Investment on Economic Growth Empirical Evidence from Bangladesh

Thanoon, M. A., \& Jarallah, R. O. (2013). Measuring The Impact of Financial Development on Economic Growth in A Sample of Developing Countries Using The Autoregressive Distributed Lag (ARDL) Model For The Period (1960-2010). TANMIYAT AL-RAFIDAIN, 35(114), 31-47.

The Arab Center for Planning. (2011). Official development aid, economic performance, and poverty with reference to Arab countries, Kuwait: Arab Center for Planning the Central Bank of JordanAnnual Statistical Bulletin,https://www.cbj.gov.jo/Pages/viewpage.aspx?pagelD=236

UNCTAD, T. (2008). Development Report 2002. New York and Geneva, 31-40.

UNCTAD. (2012). The least developed countries report 2012: Harnessing remittances and diaspora knowledge to build productive capacities.

Namdil, W. (2019). The Impact of International Finance on Economic Development in Developing Countries in Light of Economic Globalization, Ph.D. thesis, Mohamed Boudiaf University of M'sila, Algeria, 155 